Dietary compliance and changes in the nutritional status of chronic renal failure patients on conventional low-protein điet. P. D. Hart, B. Engel, A. Edwards, K. Evans F. P. Marsh \& J. Powell-Tuck

An acute-phase protein response is associated with increased resting energy expenditure in weight-losing patients with either benign or malignant pancreatic disease. J. S. Falconer, C. E. Plester, L. Douglas, K. C. H. Fearon, J. A. Ross \& D. C. Carter

Small-intestinal absorption of minerals during enteral feeding supplemented with a soya-bean polysaccharide and soya-bean oligosaccharide fibre. S. A. Kapadia, A. H. Raimundo \& D. B. A. Silk

How much energy should we prescribe for patients with chronic renal failure? B. C. N. Ang, P. D. Hart, E. Bettany, B. Engel, F. P. Marsh \& J. Powell-Tuck

Nutritional assessment in patients on home parenteral nutrition; objective measurements or clinical judgement? N. G. Egger, C. Wright, G. L. Carlson \& J. L. Shaffer

Infusion of the lithium salt of $\gamma$-linolenic acid into pancreatic cancer patients increases thymidine uptake and induces tumour necrosis factor release by peripheral blood mononuclear cells. J. S. Falconer, J. A. Ross, K. C. H. Fearon, M. G. O'Riordain \& D. C. Carter

Antimicrobial activity and long-term use of Taurolin as an additive to parenteral nutrition. D. A. Johnston, G. Phillips, J. Richards \& C. R. Pennington

Patterns of weight change in stage IV HIV infection. Derek C. MacAllan, Carole Noble, Christine Baldwin \& George E. Griffin

The recovery of labelled carbon dioxide in pregnant subjects. B. G. Cooper, D. Reaich, O. S. Olufemi \& R. Taylor

Estimation of the mass and distribution of body water in surgical patients by multiple-frequency bioelectrical impedance analysis. K. C. H. Fearon, W. J. Hannan, S. J. Cowan, C. Plester, J. S. Falconer, R. A. Richardson \& O.J. Garden

Metabolic effects of $3 \mathrm{~h}$ infusion of dopamine at $2 \mu \mathrm{g}$ and $5 \mu \mathrm{g} / \mathrm{min}$ per kg. C. J. Green, $R$. Sarginson, $R$. Duckworth, I. T. Campbell \& P. Maycock

Non-linear incorporation of tracer into non-albumin plasma protein as a result of a flooding dose of leucine. $K$. Smith, S. Downie, P. W. Watt, C. M. Scrimgeour \& M. J. Rennie

The changes in body weight and in body composition. estimated using bioelectrical impedance analysis over $72 \mathrm{~h}$ of fasting: comparison with estimates based on energy expenditure measured by indirect calorimetry. J. Webber \& 1. A. Macdonald

Long-chain triacylglycerol malabsorption and pancreatic function in children with protein-energy malnutrition complicating severe liver disease. S. Beath, I. Hooley, K. Willis, S. Johnson, D. Kelly \& I. Booth

Superior absorption of medium-chain triacylglycerols compared with conventional dietary long-chain fats in children with chronic liver disease. S. Beath, T. Johnson, K. Willis, 1. Hooley, G. Brown, I. Booth \& D. Kelly

Metabolic and inflammatory changes following laparoscopic cholecystectomy. M. S. R. Jakeways, V. Mitchell, I. A. Hashim, S. J. D. Chadwick, J. Anderson, F. Carli \& A. Shenkin

Human growth hormone improves body-weight but not disease activity in a chronic model of colitis. C. D. Weir, N. H. Anderson, M. McCaigue, M. I. Halliday \& B. J. Rowlands

Changes in short-chain fatty acids in experimental colitis. C. D. Weir, L. T. McGrath, N. H. Anderson \& B. J. Rowlands

The correction of metabolic acidosis in chronic renal failure reduces whole-body protein breakdown and amino acid oxidation. D. Reaich. T, H.J. Goodship \& S. Channon

Collagen synthesis in human bone measured using stable isotope-labelled alanine and proline. C. M. Scrimgeour. S. Downie, P. K. Rickuss \& M. J. Rennie

The effect of enteral glutamine deprivation on rat gut mucosa during a systemic injury response. Monica Wusteman, Nicola Jordan, Helen Tate, Lawrence Weaver, Steve Austin \& Marinos Elia

\title{
Trinity College, Dublin
}

15-19 JULY 1992

Undernutrition in drug addicts. Immunological study, A. Marcos, P. Varela, A. Casco, I. Santacruz \& A. Requejo

\section{University of Aberdeen}

$7 / 8$ APRIL 1993

Response of secondary hair follicles of the Cashmere goat to prolactin in vitro. M. Ibraheem, H. Galbraith, J.R. Scaife \& S. Ewen

Factors affecting the freezing point depression of milk 2. H. M. Mohammedi, M. N. I. Barclay \& P. C. Thomas

Blood acid-base and urinary excretion during chronic ingestion of a drink with acute alkalizing properties. $J . B$. Leiper \& R. J. Maughan

The effect of consuming the sodium salts of two weak organic acids for 5 consecutive days on acid-base status in man. D. Ball \& R. J. Maughan

The effect of dietary lipid manipulation on food intake, weight gain and tissue weights of rats. P. Yaqoob, E. J. Sherrington, E. A. Newholme \& P. C. Calder

The effect of dietary lipid manipulation on serum lipid concentrations and fatty acid composition. P. Yaqoob, E.J. Sherrington, D. J. Harvey, E. A. Newsholme \& P. C. Calder

Fish oil supplementation changes membrane fluidity and phospholipid profiles in humans. E. K. Lund, C. A. Farleigh, S. Ladha, L. J. Harvey \& 1. T. Johnson

Fish consumption in North Glasgow: results from the MONICA studies of 1986 and 1989. W. L. Wrieden, C. Bolton-Smith, C. A. Brown \& H. Tunstall-Pedoe

Contribution of selenium content of fish on dietary intake. M. N. I. Barclay \& A. MacPherson 


\title{
Society
}

\section{VOL. 52 No. 3 OCTOBER 1993}

\section{CONTENTS}

\section{SYMPOSIUM PROCEEDINGS}

\author{
Regents College, London \\ $2 / 3$ DECEMBER 1992 \\ THE SIR DAVID CUTHBERTSON MEDAL LECTURE 1992 \\ Chairman: M. J. RENNIE. University of Dundee
}

The immunological and metabolic effects of $\mathrm{L}$-arginine in human cancer. Kenneth G. M. Park

$387-401$

\author{
University of Aberdeen \\ 778 APRIL 1993 \\ FISH AND NUTRITION \\ Chairman.
}

Some aspects of the biology of feeding and growth in fish. Clive Talbot

Nutritional requirements of fish. Colin B. Cowey \& C. Young Cho

Variation in individual food consumption rates of fish and its implication for the study of fish nutrition and physiology. Ian D. McCarthy, Dominic F. Houlihan, Chris G. Carter \& Katerina Moutou

Epidemiological aspects of fish in the diet. Daan Kromhout

Variability of the composition of fish oils: significance for the diet. Colin F. Moffat \& Alister S. McGill

Marine oils: metabolic effects and role in human nutrition. T. A. B. Sanders

\section{ABSTRACTS OF COMMUNICATIONS}

\section{Regents College, London}

2/3 DECEMBER 1992

Protein synthesis rates in individual tissues of critically-ill patients. P. Essén, M. A. McNurlan, I. Tjäder, A. Sandgren, B. Blomqvist, J. Wernerman, A. G. Calder \& P. J. Garlick

Short-term parenteral feeding does not mitigate the decrease in albumin synthesis rates induced by interleukin-1 $\beta$ or turpentine injection in the rat. P. E. Ballmer, M. A. McNurlan, I. Grant \& P. J. Garlick

The effect of nutritional status on interleukin-6 response to elective surgery. G. E. Curtis, C. McAtear, L. Formela, A. Walsh \& A. Shenkin

Metabolic features of multiple organ failure. P. McClelland, M. Yaqoob, G. Curtis, I. A. Hashim, G. Smith, J. McLaughlin, H. Davies, S. M. Mostafa, J. M. Bone \& A. Shenkin

Manipulation of glucose utilization in multiple organ failure using somatostatin. J. Arnold, I. T. Campbell, L. J. Hipkin, S. Jenkins, E. O'Sullivan, M. Keegan, \& S. Chadwick

Metabolic and hormonal effects of hyperglycaemic glucose clamping in multiple organ failure. $C . J$. Green, $C . J$. Regan, E. O'Sullivan, S. Underhill, A. M. Clegg, D. P. M. MacLaren, L. J. Hipkin, I. A. Macdonald \& I. T. Campbell

Modification of postprandial substrate balance by the addition of fat. A. J. Griffiths, K. N. Frayn, S. M. Humphreys \& M. L. Clark

Utilization of intravenous fat in the surgical newborn infants. A. Pierro, M. O. Jones, P. Hammond, A. Nunn \& D. A. Lloyd

The effect of glucose intake on substrate utilization and energy expenditure in the surgical newborn infant. M. $O$. Jones, A. Pierro, P. Hammond, A. Nunn \& D. A. Lloyd

[Continued on p. iii of wrapper]

\section{CAMBRIDGE} UNIVERSITY PRESS

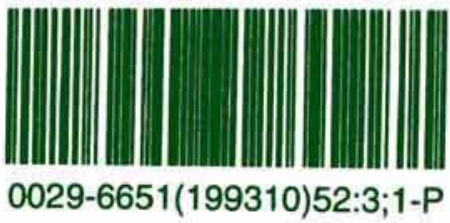

